\title{
Kompetensi Lulusan Perguruan Tinggi Vokasi Dalam Strategi Mewujudkan Sumberdaya Yang Berwawasan Entrepreneur
}

\author{
Enny Diah Astuti \\ Program Studi Administrasi Bisnis Politeknik LP3I Jakarta \\ Email : ennydiah169@gmail.com
}

\section{ARTICLE INFO}

Keywords

strategy, entrepreneur

\section{ABSTRA CT}

This study analyzes the competencies of vocational college graduates with entrepreneurial-minded resources. The problems examined in this study is about the discussion in realizing the competence of vocational college graduates in the strategy of realizing entrepreneurial-minded resources.

This research is an empirical study of student graduates in vocational colleges. The selected population of the vocational college graduates are using 20 indicators out of 135 respondents from some of the high vocational college graduates in Bekasi that most of them are from Politeknik LP3I that is spreaded out in different campuses. The data collection will use questionnaires while the analysis tool was used for Structural Equation Modeling (SEM). The results of data analysis shows that this research model is acceptable with goodness of fit. The public synopsis from the test results model that was applied to the competence of high vocational college graduates shows that strategy implementation can manifest the entreprenuerminded resources. This study also has some limits on the research agenda for the next study.

\section{PENDAHULUAN}

Setiap tahunnya angka pengangguran terus bertambah. Menurut Badan Pusat Statistik Nasional, jumlah Angkatan Kerja di Indonesia per Februari 2018 sebanyak 133,94 juta orang, naik 2,39 juta orang dibanding Februari 2017. Penambahan jumlah angkatan kerja tersebut berbanding lurus dengan peningkatan orang-orang yang bekerja pada Februari 2018 sebesar 127,07 juta orang, naik sebanyak 2,53 juta orang dibanding Februari 2017 yang hanya mencapai 124,54 juta orang. Dari 133,94 juta orang total Angkatan Kerja, sebanyak 6,87 juta orang penduduk masih mencari pekerjaan (pengangguran). Meskipun jumlah tersebut mengalami penurunan 140 ribu orang dibanding Februari 2017. Jumlah pengangguran yang turun, sejalan dengan angka Tingkat Pengangguran Terbuka (TPT) yang turun sebesar 5,13 persen.

Memasuki 2018 pengangguran terbuka saat ini sebesar 6,87 juta jiwa, sedangkan data pengangguran terdidik menunjukkan kecenderungan peningkatan dari tahun ke tahunnya. Hal ini menjadi sebuah fenomena yang mengkhawatirkan karena membuktikan bahwa pola pikir para sarjana umumnya berorientasi menjadi pegawai negeri atau karyawan swasta, padahal lapangan kerja baik di swasta dan negeri sangat terbatas dibanding dengan jumlah angkatan kerja yang dihasilkan. Sistem Pendidikan di Indonesia yang ada saat ini cenderung melahirkan para pencari kerja baru, bukan pencipta lapangan kerja. Pola pikir kaum intelek mesti di revitalisasi agar terpola menjadi job creator ketimbang menjadi job seeker.

Fakta menunjukkan bahwa pilihan yang diambil oleh sebagian besar lulusan kita saat ini lebih banyak menciptakan pengangguran dibandingkan meningkatkan jumlah lapangan kerja. Sebagai akibat dari belum pulihnya iklim investasi, terbatasnya peluang kerja, dan bertambahnya angkatan kerja baru dari pendidikan diploma dan sarjana sebesar 1,5 juta -2 juta jiwa per tahunnya maka tidak mengherankan jumlah pengangguran terus bertambah setiap tahunnya. Sudah saatnya, kita perlu mengubah pola pikir seorang lulusan perguruan tinggi khususnya lulusan vokasi dari seorang pencari kerja menjadi pencipta kerja. Semangat entrepreneur harus ditanamkan dalam diri generasi bangsa kita sejak dini. Sikap keragu-raguan untuk berpindah dari kuadran "employee" ke kuadran "pengusaha" harus dihilangkan. Kendati untuk memulai suatu usaha membutuhkan setidaknya keberanian untuk mengeksplorasi ide bisnis dan menjadikannya bernilai. 
Entrepreneurship adalah jiwa entrepreneur yang dibangun untuk menjembatani antara ilmu dengan kemampuan pasar. Entrepreneurship meliputi pembentukan perusahaan baru, aktivitas serta kemampuan managerial yang dibutuhkan seorang entrepreneur.

Intrapreneurship didefinisikan sebagai entrepreneur yang terjadi di dalam organisasi yang merupakan jembatan kesenjangan antara ilmu dengan keinginan pasar.

Sedang, Entrepreneur didefinisikan sebagai seseorang yang membawa sumber daya berupa tenaga kerja, material, dan aset lainnya pada suatu kombinasi yang menambahkan nilai yang lebih besar daripada sebelumnya, dan juga dilekatkan pada orang yang membawa perubahan, inovasi, dan aturan baru. Sementara, istilah Entrepreneurial adalah kegiatan dalam menjalankan usaha. Ada persamaan ciri dari para entrepreneur diatas adalah, dimanapun mereka berada, mereka sangat kreatif, inovatif, mampu mencari dan membaca peluang, serta berani mengambil resiko.

Entrepreneurship mempunyai dampak positif terhadap kekuatan dan stabilitas ekonomi. Salah satu dampak terpenting dari entrepreneurship adalah sebagai penyedia lapangan pekerjaan sehingga mampu menekan angka pengangguran. Kemudian dampak terpenting lain adalah Inovasi dimana mampu memberikan kekuatan ekonomi masyarakat. Inovasi mampu menciptakan sesuatu yang baru, dan merupakan isu utama dalam proses entrepreneurial. Inovasi dapat membantu individu dan bisnis untuk bekerja secara lebih efektif dan efisien. Sebagai dampak lainnya adalah globalisasi. Fenomena globalisasi sangat penting bagi perekonomian karena saling terhubung sehingga mampu menyediakan outlet untuk memasarkan produk ke luar negeri.

Menurut J.A Schumpeter dalam bukunya "The Entrepreneur as Innovator", manajer berjiwa entrepreneur juga merupakan sosok yang berambisi tinggi di dalam mengembangkan bisnisnya, energik, percaya diri, kreatif dan inovatif, senang dan pandai bergaul, berpadangan ke depan, bersifat fleksibel, berani terhadap resiko, senang mandiri dan bebas, banyak inisiatif dan bertanggung jawab, optimistik, memandang kegagalan sebagai pengalaman yang berharga (positif), selalu berorientasi pada keuntungan, dan gemar berkompetisi.

Berbeda dengan manajer yang tidak berjiwa entrepreneur. Biasanya mereka cenderung berpikir sangat rasional, suka kemapanan, dan tidak menginginkan adanya perubahan. Kerap kali terjadi mereka mengalami kesulitan dalam mengikuti gaya berpikir seorang entrepreneur. Mereka juga akan kesulitan mengikuti langkah-langkah bisnis entrepreneur. Namun ketika seorang manajer memiliki sense of entrepreneur, biasanya ia akan bisa menjadi entrepreneur sejati. Dan, apabila Anda sebagai entrepreneur telah memiliki manajer yang menjalankan usaha Anda, sebaiknya manajer perusahaan yang berjiwa entrepreneur tersebut Anda beri lagi sebuah tantangan yang lebih besar, misalnya mengelola unit usaha anda, lantas berbekal jiwa entrepreneur yang dimilikinya, ia memberanikan diri mendirikan usaha sendiri. Itu tentu saja lebih baik. Sebab tindakannya itu akan membantu menciptakan lapangan kerja, entrepreneur-entrepreneur baru pun semakin sering bermunculan.

Kondisi persaingan global dan perkembangan teknologi yang begitu cepat, membutuhkan kontribusi pendidikan dalam menghasilkan sumber daya manusia yang unggul dan berdaya saing. Pendidikan dijadikan sebagai kebutuhan dasar yang harus dipenuhi oleh masyarakat. Salah satu indikator majunya suatu bangsa ditentukan dengan indeks pengembangan kualitas sumber daya manusia, yang hasilnya didapat dari proses pendidikan yang bermutu. Kondisi persaingan dan perkembangan yang begitu cepat, membutuhkan kontribusi pendidikan dalam menghasilkan sumber daya manusia yang unggul dan berdaya saing. Pendidikan dijadikan sebagai kebutuhan dasar yang harus dipenuhi oleh masyarakat. Salah satu indikator majunya suatu bangsa ditentukan dengan indeks pengembangan kualitas sumber daya manusia, yang hasilnya didapat dari proses pendidikan yang bermutu.

Dalam perannya sebagai katalisator, akan menjadi sebuah nilai tambah apabila sebuah perguruan tinggi mampu mengubah arah kebijakan dari yang ada saat ini high learning university dan research university menjadi entrepreneurial university ataupun dengan menyeimbangkan keduanya antara High Learning and Research University dan Entrepreneurial University. Dengan paradigm change tersebut diharapkan akan menghasilkan para lulusan yang akan menjadi entrepreneur muda mandiri ataupun sebagai manajer yang berwawasan entrepreneur, yang mampu menghasilkan suatu inovasi dalam berkarya di dunia pekerjaan.

Atas dasar pemikiran diatas maka peneliti bermaksud menganalisis untuk mengetahui bagaimana kesiapan para intelektual muda kita dalam menghadapi globalisasi di masa mendatang dengan merumuskan, "Kompetensi Lulusan Perguruan Tinggi Vokasi dalam Strategi mewujudkan Sumberdaya yang berwawasan Entrepreneur"

Enny Diah Astuti (Kompetensi Lulusan Perguruan Tinggi Vokasi Dalam Strategi...) 


\section{PERMASALAHAN}

Perguruan tinggi sebagai salah satu mediator dan fasilitator terdepan dalam membangun generasi muda bangsa mempunyai kewajiban dalam mengajarkan, mendidik, melatih dan memotivasi mahasiswanya sehingga menjadi generasi cerdas yang mandiri, kreatif, inovatif dan mampu menciptakan berbagai peluang pekerjaan (usaha).

Perguruan Tinggi adalah institusi yang bisa menumbuhkan cara pandang yang tidak myopik karena memiliki tradisi dialog. Dengan dialog, pengetahuan entrepreneurship yang memiliki dua sifat yaitu tacit knowledge dan explicit knowledge bisa disebarkan dengan efek spiral. Tacit knowledge adalah bersifat personal, konteksnya spesifik, sulit untuk dikomunikasikan dan di formalisasikan. Kebalikan dengan explicit knowledge, yaitu pengetahuan yang terkodifikasi, mudah ditransmisikan secara sistematik melalui kata dan angka. Persoalan yang dihadapi oleh perguruan tinggi sekarang ini apakah sudah siap dengan infrastruktur yang memungkinkan tumbuhnya iklim kondusif untuk dialog sehingga terjadi konversi pengetahuan dari tacit knowledge menuju explicit knowledge.

\section{KAJIAN LITERATUR}

Strategi

Strategi merupakan rencana yang disatukan, luas dan berintegrasi yang menghubungkan keunggulan strategis perusahaan dengan tantangan lingkungan, yang dirancang untuk memastikan bahwa tujuan utama dari perusahaan dapat dicapai melalui pelaksanaan yang tepat oleh suatu organisasi.

Strategi adalah proses penentuan rencana para pemimpin puncak yang berfokus pada tujuan jangka panjang organisasi, disertai penyusunan suatu cara atau upaya agar tujuan tersebut dapat dicapai.

Perencanaan strategi merupakan cara yang melibatkan pemikiran melalui sebuah karya, penciptaan dari fungsi manajemen staf baru yaitu munculnya ahli perencanaan. Dimana sistem perencanaan ini merupakan strategi yang bagus sebagai suatu tahapan strategi yang akan diterapkan para pelaku bisnis, manajer perusahaan dan mengarahkan agar tidak membuat kekeliruan hal ini diungkapkan oleh Mintzberg, H.(1994:107-114).

Menurut Thompson dan Strickland (1996:177-178) ada banyak pendekatan dalam melakukan perencanaan, yaitu:

1. The Master Strategist Approach, dimana proses perencanaan sangat didominasi oleh seorang yang disebut sebagai ahli strategi. Perencanaan ini sangat sesuai diterapkan untuk organisasi yang masih bersifat sederhana dengan banyak staf karyawan yang masih belum siap untuk melakukan perencanaan.

2. The Delegate it to others, pendekatan dimana pemimpin cenderung untuk memberikan tanggung jawab pekerjaan perencanaan kepada level manajemen dibawahnya. Biasanya pemimpin yang demikian kurang menguasai bidang usaha yang dipimpinnya.

3. Model collaborative approach merupakan kerja dari seluruh anggota organisasi. Pendekatan ini memberdayakan anggota organisasi pada level menengah dan bawah, serta sejalan dengan kepentingan dan keinginan pimpinan.

4. The Champion approach, perencanaan usaha yang biasanya dilakukan pada organisasi yang berskala besar, dimana pimpinan puncak hanya tinggal melakukan koreksi dan evaluasi dari perencanaan yang diajukan oleh unit bisnis-unit bisnisnya.

Penentuan pendekatan dalam proses perencanaan strategis merupakan langkah awal yang penting dan menentukan untuk peluang diterapkannya strategi yang akan direncanakan. Pemilihan pendekatan ini sangat ditentukan oleh sifat dan skala organisasi, model dan kompetensi kepemimpinan, serta kapasitas dan kemampuan staf organisasi dalam melakukan perencanaan strategi perusahaan. Setelah melakukan perencanaan usaha, maka langkah penting selanjutnya adalah bagaimana mengimplementasikan perencanaan usaha tersebut.

\section{Entrepreneur}

Seorang, Entrepreneur didefinisikan sebagai orang yang membawa sumber daya yang berupa tenaga kerja, material, dan aset lainnya dalam suatu kombinasi yang menambahkan nilai yang lebih besar daripada 
sebelumnya, dan juga dilekatkan pada orang yang membawa perubahan, inovasi, dan aturan baru. Sementara, istilah Entrepreneurial adalah kegiatan dalam menjalankan usaha. Entrepreneurship adalah jiwa entrepreneur yang dibangun untuk menghubungkan antara ilmu dengan kemampuan pasar. Dalam Entrepreneurship meliputi pembentukan perusahaan baru, aktivitas serta kemampuan manajerial yang dibutuhkan seorang entrepreneur sedangkan Intrapreneurship didefinisikan sebagai entrepreneur yang terjadi di dalam organisasi yang terlihat sebagai kesenjangan antara ilmu dengan keinginan pasar.

Ada 4 macam jenis entrepreneur yaitu :

1. Business Entrepreneur (owner dan Professional atau yang lebih dikenal dengan Intrepreneur).

Entrepreneur yang terjadi di dalam organisasi atau dalam perusahaan dn menghubungkan antara kesenjangan antara ilmu dengan keinginan pasar, melalui penciptaan produk baru ataupun inovasi.

2. Goverment Entrepreneur

Suatu pemerintahan yang menempatkan pelayanan prima kepada masyarakat dan mitra kerjanya. Biasanya, negara dengan pola pemerintahan entrepreneur sangat diminati oleh pebisnis entrepreneur.

3. Academic Entrepreneur

Entrepreneur yang berperan dalam dunia keilmuan dan pendidikan. Kelompok ini selalu berpikir kreatif dan tekun mengembangkan ilmu sehubungan dengan banyaknya tantangan jaman. Lebih terbuka, aktif meneliti atau mendidik, dan tidak terjebak kepada kejenuhan intelektual.

4. Social Entrepreneur

Menjalankan dan mengelola organisasi non-profit untuk tugas sosial yang mereka yakini bisa memperbaiki kehidupan masyarakat.

Persamaan ciri dari para entrepreneur diatas adalah, dimanapun mereka berada, mereka sangat kreatif, inovatif, mampu mencari dan membaca peluang, serta berani mengambil resiko. Menurut Basrowi (2011:29) dalam kompetensi kewirausahaan, seorang entrepreneur yang sukses pada umumnya adalah mereka yang memiliki kompetensi, yaitu seseorang yang memiliki ilmu pengetahuan, ketrampilan dan kualitas individu ysng meliputi sikap, motivasi, nilai serta tingkah laku yang diperlukan untuk melaksanakan kegiatan. Ketrampilan yang harus dimiliki (Suryana, 2003) seorang entrepreneur adalah sebagai berikut:

1. Managerial skill

2. Conceptual skill

3. Human skill (ketrampilan memahami, mengerti, berkomunikasi dan berelasi).

4. Decision making skill (ketrampilan merumuskan masalah dan mengambil keputusan).

5. Time managerial skill (ketrampilan mengatur dan menggunakan waktu).

Kompetensi diartikan sebagai pengetahuan, ketrampilan, dan kemampuan individu yang langsung berpengaruh pada kinerja entrepreneur yang merupakan tujuan yang ingin dicapai.

\section{METODE PENELITIAN}

Penelitian ini bertujuan untuk menganalisis kompetensi terhadap lulusan perguruan tinggi, pembelajaran organisasi, lingkungan eksternal dan inovasi dalam strategi mewujudkan manajer yang berwawasan entrepreneur. Berdasarkan pengelompokan tersebut, maka penelitian ini termasuk penelitian penjelasan (explanatory research) karena penelitian ini bermaksud menjelaskan hubungan kausal antar variabel melalui pengujian hipotesis.

Unit analisis penelitian ini adalah para lulusan perguruan tinggi yang sudah memasuki dunia kerja ataupun bidang usaha. Responden penelitian ini di fokuskan kepada para alumni perguruan tinggi. Penelitian ini akan menggambarkan persepsi para lulusan perguruan tinggi vokasi mengenai pembelajaran organisasi, pengaruh lingkungan eksternal, strategi inovasi, dan jiwa entrepreneurship. Dipilihnya para alumni perguruan tinggi yang sudah memasuki dunia kerja atau bidang usaha sebagai responden, karena dianggap paling mengetahui kondisi di perguruan tinggi masing-masing disaat menempuh kuliah sesuai dengan variabelvariabel yang akan digunakan dalam penelitian ini.

Teknik analisis ditujukan untuk mengintrepretasi dan menganalisis data dalam penelitian. Analisis data yang digunakan adalah statistik deskriptif untuk menggambarkan jawaban responden dari berbagai konstruk yang dikembangkan serta statistik diferensial untuk pengujian hipotesis, khususnya dengan menggunakan analisis dalam model SEM.

\section{PEMBAHASAN}

Enny Diah Astuti (Kompetensi Lulusan Perguruan Tinggi Vokasi Dalam Strategi...) 
Gambaran umum obyek penelitian

Entrepreneur yang sukses pada umumnya adalah yang memiliki kompetensi, yaitu sesorang yang memiliki ilmu pengetahuan, ketrampilan dan kualitas individu yang meliputi sikap, motivasi, nilai dan tingkah laku yang diperlukan dalam dunia pekerjaan.

Mungkin kita pernah mendengar bahwa keluarga yang kaya akan memunculkan anak-anak yang kaya karena mereka telah terbiasa hidup kaya. Begitupula ada yang menganggap bahwa seseorang menjadi seorang pengusaha karena mereka dilahirkan dalam keluarga kaya baik dari orang tuanya, kakek neneknya ataupun sebagian besar keluarga besarnya karena mereka semua berdarah pengusaha. Anggapan seperti ini merupakan pemikiran yang keliru tetapi tidak bisa dipungkiri juga bahwa banyak pengusaha lahir dari keluaarga atau keturunan pengusaha, tetapi bukan berarti diturunkan secara genetis. Mungkin saja hal ini terpacu karena mereka dibesarkan di lingkungan pengusaha sehingga memacu mereka untuk berkiprah menjadi pengusaha juga.

Menjadi entrepreneur merupakan hak semua orang, tinggal bagaimana kita melihat peluang yang ada maupun berusaha untuk menjadi seorang pengusaha. Jiwa entrepreneurlah yang perlu di tanamkan dalam jiwa anak muda kita terutama mereka yang masih mengenyam pendidikan di bangku kuliah agar menghasulkan lulusan yang memiliki kompetensi, trampil; dan siap kerja. Banyak sekali cara yang bisa dilakukan untuk mendorong motivasi para lulusan perguruan tinggi vokasi baik melalui pendidikan formal, seminar-seminar kewirausahaan, pelatihan maupun otodidak. Yang terpenting dari itu semua mereka harus memiliki jiwa entrepreneurship, percaya diri yang tinggi, inisiatif, kreatif dan inovatif serta memp[unyai jiwa kepemimpinan dan menyukai tantangan. Atas bekal tersebur pasti akan terwujudpara lulusan perguruan tinggi vokasi yang berkompeten dsebagai sumberdaya yang siap terjun ke dunia kerja yang memiliki wawasan entrepreneur.

\section{Analisis Eksplanatif Variabel}

Unit analisis penelitian ini adalah para lulusan perguruan tinggi yang sudah memasuki dunia kerja ataupun bidang usaha. Responden penelitian ini difokuskan kepada para alumni perguruan tinggi. Penelitian ini akan menggambarkan persepsi para lulusan perguruan tinggi mengenai pembelajaran organisasi, pengaruh lingkungan eksternal, strategi inovasi, dan jiwa entrepreneurship. Dipilihnya para alumni perguruan tinggi yang sudah memasuki dunia kerja atau bidang usaha sebagai responden, karena dianggap paling mengetahui kondisi di perguruan tinggi masing-masing disaat menempuh kuliah sesuai dengan variabel-variabel yang akan digunakan dalam penelitian ini.

Populasi dalam penelitian ini adalah para lulusan perguruan tinggi yang sudah memasuki dunia kerja ataupun membuka bidang usaha sendiri. Penentuan jumlah sampel dilakukan dengan mempertimbangkan syarat yang harus dipenuhi jika menggunakan SEM, yaitu jumlah sampel berkisar antara 100-200 dan minimal adalah lima kali jumlah indikator. Penelitian ini menggunakan 20 indikator untuk memenuhi syarat minimal sampel diambil 135 responden dari para mahasiswa lulusan beberapa perguruan tinggi vokasi di Bekasi yang sebagian besar berasal dari Politeknik LP3I yang tersebar dari beberapa kampus.

\section{Persepsi responden terhadap variable kompetensi lulusan}

Hasil responden terlihat bahwa kompetensi lulusan vokasi sangat besar pengaruhnya dalam penetapan strategi bisnis suatu usaha, hal ini digambarkan dalam jumlah prosentase sebesar $57.94 \%$. Sebagai lulusan perguruan tinggi vokasi yang selalu mencermati perkembangan teknologi yang berkembang untuk mendukung kemajuan usaha dan perkembangan usaha sebanyak $60.75 \%$. Dari data responden terlihat bahwa perkembangan minat dan kompetensi lulusan vokasi sangat berubah-ubah dan bersifat dinamis, hal ini dikarenakan unit usaha-usaha yang baru dirintis masih dalam skala kecil sehingga harus selalu mampu menyesuaikan dengan kondisi perkembangan. Beberapa contoh usaha yang sukses khususnya usaha yang berbasis online dan kuliner sangat diminati oleh para lulusan vokasi sebagai lulusan yang siap kerja untuk terjun menjadi entrepreneur muda hal ini tercermin dengan prosentase sebesar $62.62 \%$. Dunia entrepreneurship yang sangat dinamis harus mampu melihat dan menyesuaikan dengan perkembangan pasar untuk mendukung kemajuan usaha, sehingga diperlukan stategi yang sangat kuat dari para lulusan perguruan tinggi vokasi yang ingin terjun langsung sebagai entrepreneur hal ini terlihat prosentase dari para responden sebesar 67.29\%. Sedangkan kompetensi yang dimiliki oleh para lulusan vokasi dinilai tidak terlalu berpengaruh besar dalam menciptakan entrepreneur seperti terlihat dalam sebaran prosentase yang cukup berimbang dari pendapat para responden yaitu $32.71 \%$ dan $36.45 \%$ tetapi masih dalam kategori skor yang cukup yaitu 423 ini menunjukkan bahwa masih kurangnya minat dari para lulusan itu sendiri. Kompetensi 
lulusan vokasi dinilai sangat berpengaruh dalam menentukan langkah strategi dan harus mampu menyediakan sumberdaya yang sesuai dengan permintaan pasar hal ini tercermin dari hampir sebagian responden setuju yaitu dengan prosentase sebesar $65.42 \%$

Persepsi responden terhadap variable sumberdaya

Dari data responden dapat diintrepretasikan dari angka prosentase sebanyak $56 \%$ bahwa sangat dibutuhkan keahlian manajerial dalam mengelola usaha sedangakan secara matrik skor yang didapatkan yaitu sebesar 477 termasuk dalam skala sangat baik. Dari tabel yang diisi oleh responden terlihat bahwa pemilik usaha sebaiknya menjalankan sendiri usahanya, dalam tabel diatas terdapat $45.79 \%$ pemilik usaha yang menjalankan sendiri usahanya tetapi ada juga yang mempercayakan pengelolaannya kepada supervisor atau manager yaitu sebanyak $32.71 \%$. Penilaian secara skor terlihat cukup baik yaitu sebesar 450 dalam skala matrik. Tingkat kepercayaan staff dan karyawan terhadap pengelolaan manajerial sangat besar, hal ini di intrepretasikan dari data responden yaitu sebesar $51.4 \%$ dan 44.86 responden yang menjawab setuju. Pengelola usaha harus mempunyai pemikiran dan bersikap sebagai pemilik usaha yang di intrepetasikan sebanyak 55.14\% Terlihat dari responden bahwa profesionalitas dalam bekerja akan menghasilkan output yang baik bagi perusahaan yaitu sebanyak 58.8\% Kemampuan karyawan dalam bekerja terlihat sesuai dengan keahlian di bidang masing-masing terbaca sebanyak $52.4 \%$ atau dengan skor 477 dimana dikategorikan dalam skala baik.

Persepsi responden terhadap variable wawasan entrepreneuship

Kompetensi lulusan tidak hanya dalam hal ilmu pengetahuan tetapi juga lebih ditekankan dalam ketrampilan dan kualitas individu, hal ini terlihat dari banyaknya jumlah responden yaitu sebesar $61.68 \%$ dengan skor 493. Dalam menciptakan lulusan yang berdaya saing perguruan tinggi vokasi berupaya menumbuhkan jiwa entrepreneur kepada mahasiswanya untuk menghasilkan output yang lebih ditekankan pada implementasi dalam pembelajaran, hal ini tercermin dari jawaban responden yang cenderung merata dan lebih ke arah netral dengan prosentase tertinggi 30.84\%. Dari para responden terlihat bahwa terbukanya peluang untuk menjadi pengusaha di masa sekarang semakin besar dimana pasar semakin luas sehingga dituntut untuk dapat menyesuaikan produk-produknya agar lebih dapat diterima di masyarakat sebanyak $65.42 \%$. Dengan semakin berkembangnya teknologi yang dapat diterapkan dalam berbagai usaha di masyarakat diharapkan dapat bersaing diantara usaha sejenis di bidangnya, dimana secara prosentase $62.62 \%$. Calon pengusaha ataupun pengelola hendaknya harus senantiasa memperhatikan mutu dan kualitas produkproduk yang akan diluncurkan, hal ini tercermin pada jawaban responden sebanyak $63.55 \%$. Sekalipun usaha yang dibangun tergo;ong baru sebagai entrepreneur muda dituntut untuk senantiasa konsisten terhadap mutu dan pelayanan terhadap pelanggannya yaitu dengan prosentase 69.16. Kerjasama tim dan seluruh karyawan yang baru dibentuk serta bersikap tanggap terhadap aktifitas usaha merupakan budaya kerja yang positif dalam perusahaan dengan prosentase $60.75 \%$. Sikap inisiatif, mental wirausaha dan kemandirian dalam bekerja sangat berpengaruh terhadap aktifitas usaha yaitu sebanyak $58.88 \%$.

\section{SIMPULAN DAN SARAN}

Berdasarkan hasil analisis terhadap data yang berhasil dihimpun dilapangan, maka dapat diambil beberapa kesimpulan sebagai berikut:

Kompetensi lulusan perguruan tinggi vokasi berpengaruh dalam strategi mewujudkan sumberdaya mahasiwa lulusan. Pada output SEM diperoleh koefisien 0.87 Untuk menguji apakah Kompetensi lulusan perguruan tinggi vokasi berpengaruh dalam strategi mewujudkan sumberdaya mahasiswa lulusan. terlihat dari t-hitung $7.76>1.96$ (t-tabel alpha 5\%) artinya Kompetensi lulusan berpengaruh nyata positif terhadap strategi mewujudkan sumberdaya mahasiswa lulusan berpengaruh positif terhadap Kompetensi lulusan perguruan tinggi vokasi berpengaruh dalam strategi mewujudkan sumberdaya mahasiswa lulusan. Pada output SEM diperoleh koefisien sebesar 0.55. Untuk menguji apakah Kompetensi lulusan perguruan tinggi vokasi berpengaruh dalam strategi mewujudkan sumberdaya mahasiswa lulusan bisa dilihat dari nilai t-hitung $2.52>1.96$ ( $\mathrm{t}$-tabel alpha 5\%) artinya Kompetensi lulusan perguruan tinggi vokasi berpengaruh nyata dalam strategi mewujudkan sumberdaya mahasiswa lulusan yang berwawasan entrepreneur. Jika Kompetensi lulusan perguruan tinggi vokasi ditingkatkan maka akan meningkatkan lulusan sumberdaya mahasiswa. 
Semakin matang Kompetensi lulusan perguruan tinggi vokasi yang diterapkan pada strategi maka semakin lulusan sumberdaya mahasiswa. yang dihasilkan. Namun jika Kompetensi lulusan perguruan tinggi vokasi yang diterapkan buruk maka lulusan sumberdaya mahasiswa.yang dihasilkan akan buruk pula. Semakin baik Kompetensi lulusan perguruan tinggi vokasi yang dikembangkan dalam strategi mewujudkan sumberdaya lulusan, maka semakin baik pula sumberdaya mahasiswa lulusan yang berwawasan entrepreneur.

\section{SARAN}

Bagi Perguruan Tinggi Vokasi

Aspek kompetensi lulusan perguruan tinggi vokasi sangat penting terhadap hasil mahasiswa lulusan karena diharapkan para lulusan perguruan tinggi vokasi menghasilkan tenaga yang memiliki jiwa entrepreneur terampil yang siap kerja penuh daya saing, kreatif dan inovatif sehingga semakin banyak minat perusahaan memberikan peluang-peluang terhadap hasil lulusan perguruan tinggi vokasi. Demikian juga dengan strategi kompetensi berpengaruh erhadap lulusan yang dihasilkan sehingga para lulusan juga memiliki inisiatif, ide-ide kreatif menciptakan peluang usaha dan lapangan kerja bagi dirinya sendiri dan menggerakkan ekonomi masyarakat sekitar di lingkungannya, hal ini perlu terus dikembangkan dan ditingkatkan ke depannya.

\section{Bagi Peneliti lain}

Penelitian mendatang hendaknya melakukan replikasi penelitian untuk cakupan penelitian yang lebih luas. Penelitian juga dapat dilakukan tidak terbatas pada kompetensi lulusan dan strategi yang diperlukan bagi perguruan tinggi vokasi, tetapi dapat diperluas ke bidang yang lain. Dengan harapan akan membantu mendapatkan sampel ysng lebih baik lagi sehingga diharapkan mendapatkan hasil yang lebih akurat.

\section{DAFTAR PUSTAKA}

Basrowi, (2011).”Kewirausahaan untuk Perguruan Tinggi, Juni 2011, Bogor.

Ferdinand, Augusty (2000), "Manajemen Pemasaran : Sebuah Pendekatan Stratejik", Research Paper series, No. I,p. $1-55$

Mintzberg, H.(1994). “The Fall and Rise of Strategic Planning.” Harvard Business Review. January-February :pp.107-114. Prentice Hall International

Puspowarsito, AH, (2006), Hubungan Antara Keusahawanan Serikat dengan Prestasi Serikat : Campuran Pemasaran dan Perserikatan Bisnis sebagai Moderator, Disertasi, Universitas Sains Malaysia (USM)

Riyadi, LB.(2001).’Perijinan dan Sertifikat Industri Kecil dan Menengah, Juni 2001, Yogyakarta.

Suhartini,K., 2007, Jurnal Mnajemen dan Bisnis Sriwijaya vol. 5, No 9 Juni 2007, Program Magister Management, Universitas Sriwijaya

Supratiwi, W., dan Isnalita. (2003). Kajian Pemetaan Usaha Kecil dan Menengah dalam Rangka PraRestukturisasi, Majalah Ekonomi, Tahun XIII, No. I April, Hal. 47-68

Thompson, Strickland., 1996. Strategic Manajemen, pp 177-178.

-------., 2011, Buletin Majalah Kewirausahaan, edisi Maret 2011, Program Magister Fakultas Ekonomi Universitas Padjajaran, Bandung 